
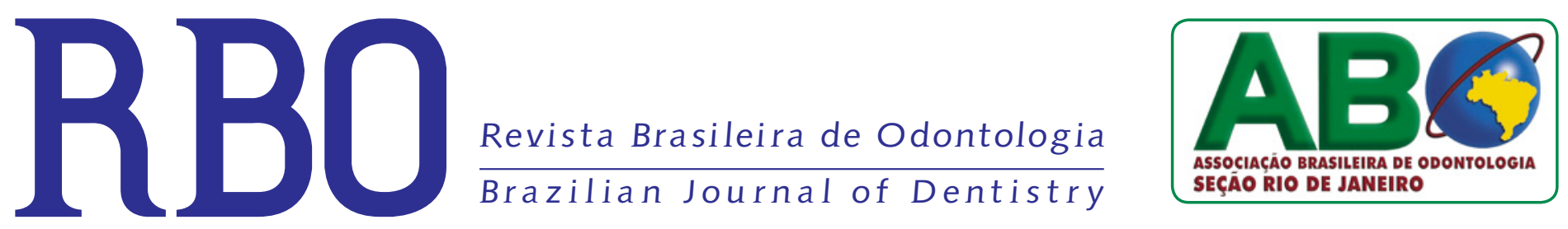

E D | T O R | A L

\title{
Good news about the future
}

\section{RBO volume $75 \cdot 2018$}

Founded in 1943 by Orandino Prado Filho, Antônio Leme Jr. and Homero Coutinho A quarterly journal published by the Brazilian Dental Association - Section: Rio de Janeiro (ABO-RJ)

CNPJ 34.052.217/0001-67 / RBO is indexed by Index Dental to Literature, BBO, Lilacs, Latindex, Scirus for Scientific Information Only, Ulrich's Directory Periodicals, Medline and Pubmed.

\section{Editor-in-Chief and Director}

Prof. Geraldo Oliveira Silva-Junior

Scientific Editor

Profa. Bruna Lavinas Sayed Picciani

\section{Advertising}

revista@aborj.org.br

Phone: +55-21-2504-0002 Ext.: 220

\section{Editorial Production}

ABO-RJ's Communication Center

Assistant Editor and Journalist

Cíntia de Assis (MTB 20209)

Graphic Designer

Valéria Pontes

Online Editorial Production

Luciana Manta (CRB-74451)

Administrative Assistant

Luciano Carvalho

General Composing and Administration

ABO-RJ Headquarters - R. Barão de Sertório, 75

Rio Comprido - Rio de Janeiro - RJ - Brazil

CEP: 20.261-050 - Phone: +55-21-2504-0002

(Ext.: 219) Fax: +55-21-2504-3859

Website: www.aborj.org.br

RBO online: www.revista.aborj.org.br

E-mail: scientific@revista.aborj.org.br

\section{I} $\mathrm{n}$ this 75 th volume of the Brazilian Journal of Dentistry a number of changes happened that led us very proud of. Following the main goals of increasing the qualis score and gaining international visibility, we have made important changes as: 1 . Translation of the journal's name and website; 2. Inclusion of author's Mini Curriculum, contributions and ORCID; 3. Creative Commons Licence on all pages of the papers; 4. Continuous flow of publications; 5 . Diadorim and DOAJ index; 6. Publication of Annals of Congress; 7. Several campaigns aiming to increase the number of international authors and reviewers. We are aware that some changes are still needed, since everything in life and science has to transform and improve in order to always provide us the best things.

The editorial board hopes that, joining efforts with authors and readers, we will have the chance of having a better Brazilian journal. We wish you a Happy Christmas and all the best for 2019 !

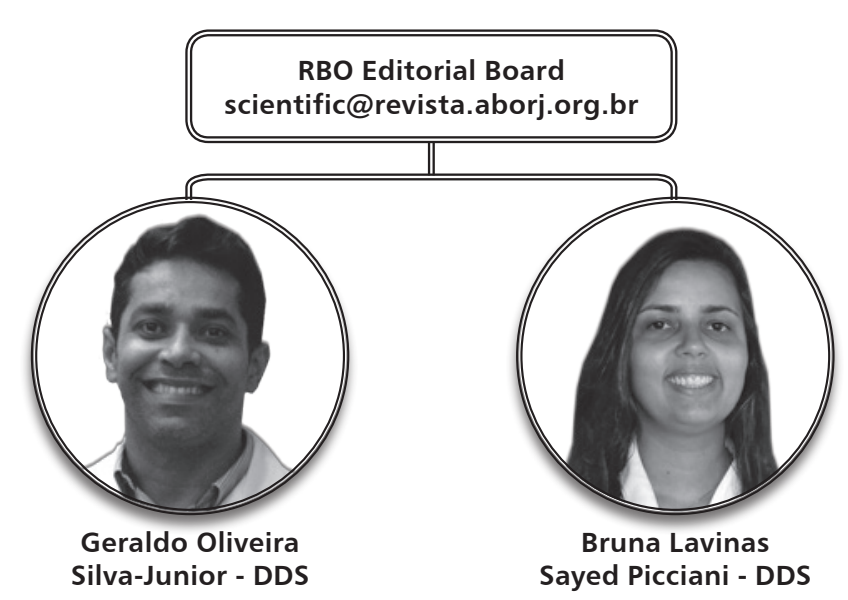

Executive Board of the Brazilian Dental Association - Section: Rio de Janeiro (ABO-RJ)

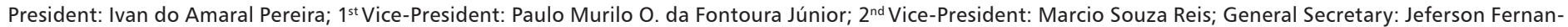

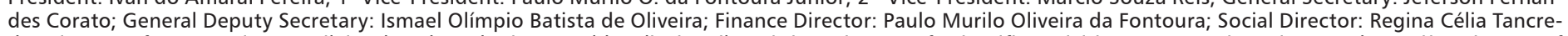

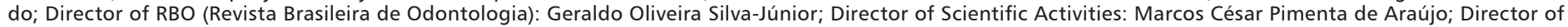

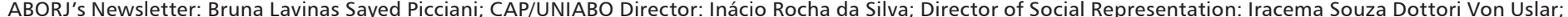

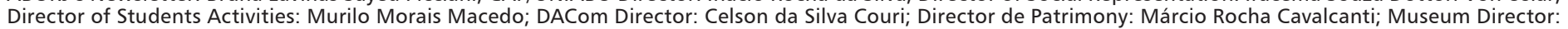

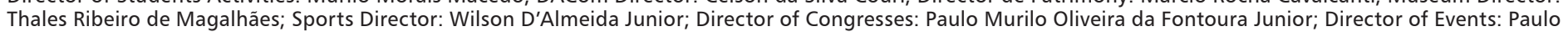

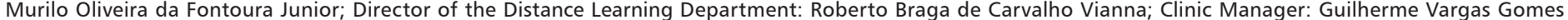

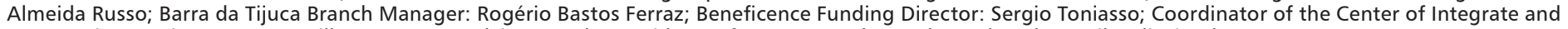
Community Dentistry (COIC): Guilherme Russo; Advisors to the President: Afonso Fernandes Rocha and Paulo Murilo Oliveira da Fontoura. 